\title{
Farmers' rice knowledge and adoption of new cultivars in the Tillabéry region of western Niger
}

\author{
Mounirou Sow ${ }^{1}$, Papa Abdoulaye Seck${ }^{1}$, Illiassou Mossi Maiga ${ }^{2}$, Mark Laing ${ }^{3}$, Rodomiro Ortiz ${ }^{4}$ \\ and Marie-Noelle Ndjiondjop ${ }^{1 *}$
}

\begin{abstract}
Background: Tillabéry is the main rice growing region of Niger, and it includes both irrigated and lowland rice. Rice production has stagnated due to several factors this research investigated through farmers' eyes.

Methods: Semi-structured group discussions were carried out in 14 villages in which 153 farmers, after giving their informed consent, were individually subjected to a questionnaire, and farmers' fields and storage facilities were visited.

Results: Fields were larger in private irrigation and lowland agrosystems compared to those in public irrigation schemes. The local farmers' union was the only formal seed dissemination system. Farmers exchanged seed as well as did re-seeding of leftovers from the previous harvest. They indicated Rice yellow mottle virus (RYMV) and bacterial leaf blight (BLB) as the most prevalent biotic stresses in the irrigated agrosystems, but the RYMV-susceptible cultivars IR1529 and 'Waihidjo' are still the most popular varieties. Floods, birds, and hippopotamuses were the most damaging agents in lowland agrosystems where the landrace 'Degaulle'/D5237 was the preferred cultivar.

Conclusions: Rice farmers in the region of Tillabéry were aware of the RYMV, could provide good descriptions of its symptoms, but could not establish the real causes of the disease nor its relationship with insects' prevalence and other cultural practices. However, traditional management strategies were implemented to reduce RYMV epidemics. This situation showed that farmers in the region of Tillabéry were willing to face RYMV epidemic outbreaks while growing their preferred rice cultivars. Good seed availability and absence of seed policy at the time of this study were also detected as bottlenecks in rice production increase in Tillabéry.
\end{abstract}

Keywords: Bacterial leaf blight, Farmers' perceptions, Participatory rural appraisal, RYMV, Seed

\section{Introduction}

Rice is the third most important crop in Niger and shows the most rapidly increasing consumption. Rice imports grew from 40,000 $t$ in 1995 to $210,000 t$ in 2005 at a cost of US\$ 71.4 million in a country where nearly $60 \%$ of the population lives below the poverty line $[1,2]$. Rice is produced mainly in the region of Tillabéry (75\% national production) where about $1 / 7$ of Niger's population live $[3,4]$. With 100,000 ha of arable and irrigable lands, this region of Tillabéry has nearly $50 \%$ of the country's irrigable land.

There are 29 irrigated rice schemes (with double cropping each year) that cover 7,432 ha (85.3\% of the national irrigated schemes) in Tillabéry. The average rice grain

\footnotetext{
* Correspondence: m.ndjiondjop@cgiar.org

${ }^{1}$ Africa Rice Center (AfricaRice), 01 BP 2031 Cotonou, Benin

Full list of author information is available at the end of the article
}

yield in this agrosystem is 3.5 to $4.5 \mathrm{t} \mathrm{ha}^{-1}[5,6]$. This intensive system, under the control of local farmer unions and supervised by the Office National des Aménagements Hydro-Agricoles (ONAHA), currently produces 30,000 to $35,000 \mathrm{t} \mathrm{year}^{-1}$. Private irrigated systems with individual water pumps are also found in this area. The irrigated ecosystems are planted only with improved Asia-type (Oryza sativa) cultivars. The traditional rice growing in the Tillabéry region accounts for about $62.13 \%$ of lowland rice production, including lowland deep-water and floating agrosystems along the Niger River. Rice grain yields are low (0.9 to $1.5 \mathrm{t} \mathrm{ha}^{-1}$ ) with a total yearly production around $55,631 \mathrm{t}$ [6]. The rainfed lowland agrosystems are sown with both improved and traditional Asia-type cultivars, while the deep-water and floating agrosystems are sown mostly with

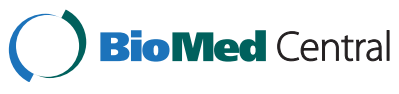

(c) 2015 Sow et al.; licensee BioMed Central. This is an Open Access article distributed under the terms of the Creative Commons Attribution License (http://creativecommons.org/licenses/by/4.0), which permits unrestricted use, distribution, and reproduction in any medium, provided the original work is properly credited. The Creative Commons Public Domain Dedication waiver (http://creativecommons.org/publicdomain/zero/1.0/) applies to the data made available in this article, unless otherwise stated. 
African rice (Oryza glaberrima) and a few traditional Asiatype cultivars.

Rice has been the staple food for people in the western zone for centuries. The Wogo and Songhai (Gaoboro) peoples are traditional rice growers. The Niger River splits the area into many islands, where submergible basins were used for rice cropping [7]. During the 1980s, Niger invested in the development of large irrigated areas for rice cropping intensification. These irrigated areas were cropped with high yielding Asian rice cultivars IR1529 and BG90-2 that brought the emergence of several pathogens, for example, the Rice yellow mottle virus (RYMV) was first reported in 1984 [8]. The Asian rice cultivars were the causes of the first RYMV outbreaks leading to grain yield losses ranging from $58 \%$ to $68 \%[8,9]$. RYMV remains on more than 12,000 ha of rice along the Niger (west) and the Komadougou (east) Rivers. This is more than $1,000 \mathrm{~km}$ from the first sites where RYMV was noticed initially [10]. In 2012, a country-wide survey of RYMV incidence reported an average of $5 \%$ to $90 \%$, with associated yield loss ranging from $35 \%$ to $71 \%$, highlighting the persistence of RYMV in irrigated rice agrosystems of Niger [11].

Although RYMV has been detected in all seed parts of several rice genotypes at high rates (65\% to $100 \%)$, there is no evidence of seed transmission [12]. However, rice seedbeds were pointed out as primary sources of RYMV infections [13].

Evidence of major changes in the homeland of the Wogo people in the region of Tillabéry are available in the literature and were observed during a rice germplasm collecting mission in $2008[7,14]$. In excess of $80 \%$ of African rice landraces identified by Bonkoula and Miezan [5] are not any longer in the canton of Sinder, home of the Wogos. The highly RYMV-susceptible Asian rice cultivar IR1529 is still grown in most of the irrigated schemes, despite the availability of RYMV-tolerant rice cultivars such as WITA8 and WITA9, which were bred by AfricaRice and released in 1997 by the National Institute of Agricultural Research in Niger (INRAN). A 'farmer variety' (belonging to the Asian rice) named 'Kassimo' or 'Waihidjo' has been grown in $60 \%$ of the irrigated rice fields of the region. This 'farmer variety' was likely derived through mass selection made on IR1529 by a farmer of the village of Darbani. Surprisingly, this 'farmer variety' had not been tested for RYMV resistance nor disseminated by the INRAN or the ONAHA, before being grown by farmers on a large scale.

Apparently, the absence of farmers' upstream participation in the identification of breeding target traits could explain the mitigated impact of crop research in sub-Saharan Africa [15]. Participatory research has been promoted worldwide to understand farmers' knowledge and perception of local production systems and stimulate their participation in generating better-adapted solutions [16-18]. The idea is to generate information about target population's knowledge and opinions about their production system and to use the information to design and manage future development projects. In plant breeding, such approach may enhance farmers' adoption of integrated pest management packages. Among participatory research methods, rapid rural appraisal and participatory rural appraisal (PRA) are powerful tools to rapidly accumulate information on rural issues in natural resources management and conservation, agriculture, health and nutrition, and other livelihood aspects with farmers' involvement [19].

The main objective of this research was to gather information on farmers' perception of main constraints to rice production and the seed sector in the region of Tillabéry. There were five questions that our research addressed: (a) Why farmers were still growing the RYMV-susceptible cultivar IR1529, despite the availability of RYMV tolerant cultivars for about one decade? (b) Why RYMV tolerant rice cultivars such as WITA8 and WITA9 did not replace the RYMV susceptible cultivar IR1529 in farmers' fields? (c) Which were the farmers' preferred rice cultivars in the region of Tillabéry? (d) What were the seed dissemination channels? (e) What were the main constraints to rice production in the region and what was the extent of knowledge of RYMV by farmers? To address these questions, a PRA was conducted in the three rice agrosystems to understand farmers' perception and their management of the main constraints and their rice varietal preference as well as their management of local varietal diversity. The ensuing information will be further used to deploy new rice cultivars with the aim of reducing the damaging effects of RYMV on irrigated and lowland rice of the region, which may improve farmers' livelihoods.

\section{Material and methods \\ Sampling and interview techniques}

We selected 14 representative villages of the three rice agrosystems in the region (Figure 1) and interviewed therein 6 to 18 farmers with their prior informed consent. No ethical issues, as defined in the EU 7th Framework Program guide to applicants, was identified for this research. Several techniques such as iteration, probing, direct observation, and pairwise ranking were used [16]. Semi-structured interviews were conducted first to obtain community level information on varietal diversity, seed sources, and constraint perceptions, and thereafter farmers were interviewed individually about their cultural practices, varietal diversity, awareness of major diseases, and knowledge of RMYV. Additionally, fields were revisited during the preparation of seedbeds for the second cropping period and rice seeds were collected. 


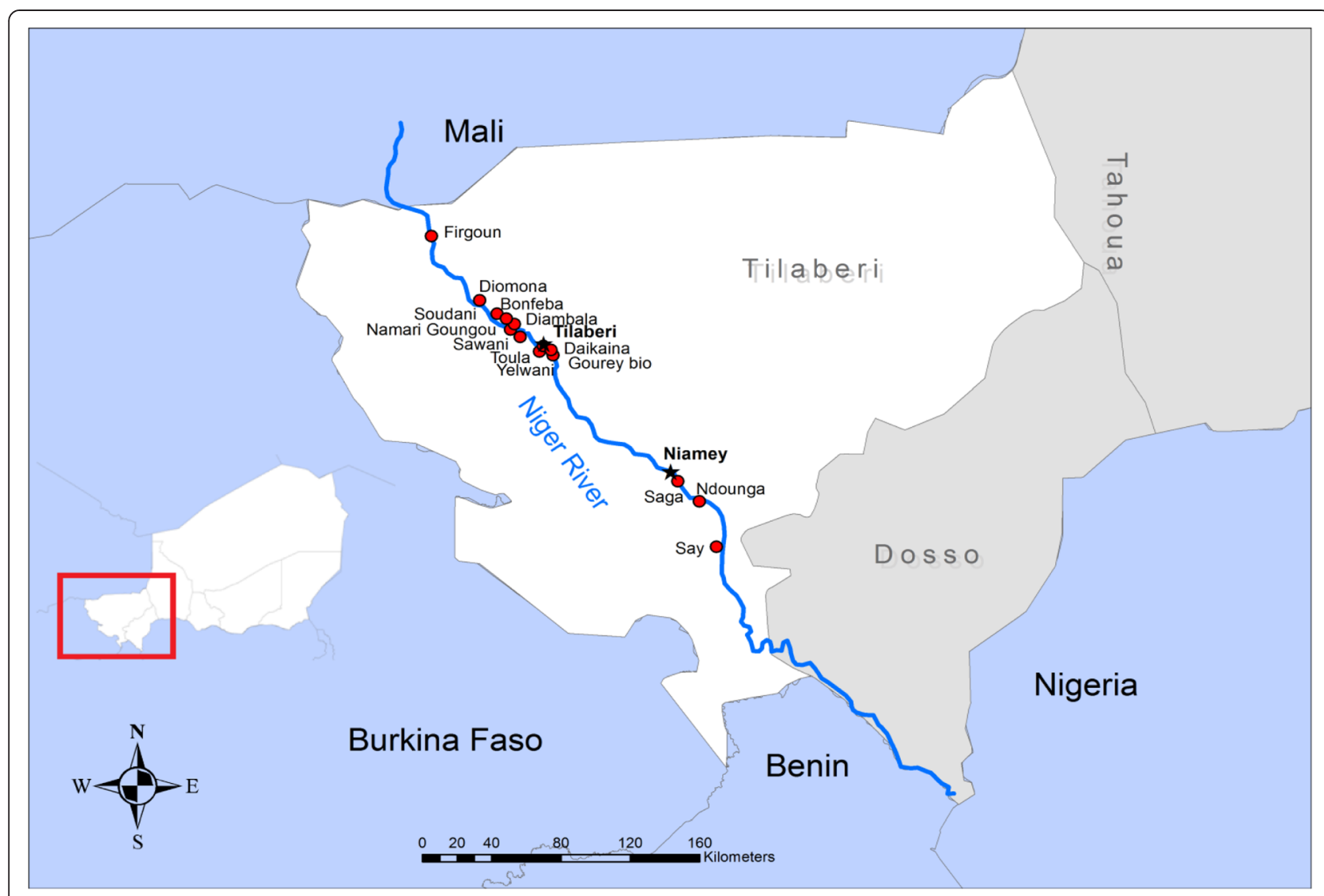

Figure 1 Tillabéry (also writing Tilaberi) region map showing the villages included in participatory rural appraisal.

\section{Data analysis}

An Access $^{\oplus}$ database was used to capture the data generated by the PRA, and the SPSS 17.0 software was used for data analysis. Means and frequencies were computed and significance tests performed.

\section{Results and discussion}

Socio-economic characteristics, information flow, and gender in the rice sub-sector

A total of 153 farmers from 14 villages participated in our PRA, of which $98 \%$ were male and only $2 \%$ were female. Their age ranged from 22 to 78 (mean $=47.8 \pm 9.6$; median $=48$ ). The time spent in a village by a farmer ranged from 15 to 78 years ( mean $=47.7 \pm 9.9$; median $=47$ years ) There were 129 farmers (84.3\%), including three women, who were members of the local farmers' union that are found in all villages with irrigated areas under the supervision of the ONAHA. The duration of their membership varied from 1 to 35 years (mean $=14 \pm 8.6$ ). About 94.1\% of the farmers considered agriculture to be their main activity, 6\% considered it as secondary activity, and 3.2\% as tertiary activity. About $4 \%$ were primarily domestic workers or laborers, and 1.3\% pursued other work. More than half $(53.6 \%)$ of them participated in training on agriculture and $51 \%$ in a rice cultivation workshop. Most of the farmers had a source of information on agriculture.

Their source of agricultural information included the local farmers' union (88.3\%), the agricultural extension service of the nearest town (5.3\%), and other fellow farmers $(2.6 \%)$. About $3.9 \%$ of interviewed farmers did not have any source of agricultural information and thus relied solely on their traditional practices. In addition, $88.2 \%$ of the farmers accessed credit through their local farmers' union in the form of fertilizers, pesticides, and seeds. Although most farmers relied on well-organized local unions for agricultural information, input supply, and access to credit, these local farmers' unions lack motivating and innovative methods to continuously remind farmers about enhancing rice production through right sowing date, use of certified seeds, transplanting densities, fertilizer doses and periods of application, and good cropping practices. Timely and right information could also benefit Niger's rice farmers as well as the environment and human health by creating awareness regarding the excessive use of fertilizers, herbicides, and pesticides in a context of global water scarcity. For example, weed resistance to Londax ${ }^{\mathrm{TM}}$ - the main herbicide used by Tillabéry rice farmers - is already known in California 
[20], and its careless use in rice fields could lead to a major problem in Niger.

Very few women were interviewed in our semi-structured discussions and individual questionnaires. This situation reflects that women in Niger were not involved in rice cultivation, which differs to what was noted in Mali [16]. Women were principal actors in postharvest activities such as processing, parboiling, and selling as were also observed in Benin [21]. A few women farmers were exploiting their rice fields for less than 10 years and used daily workers.

\section{Cropping systems and post-harvest}

Two main rice agrosystems, namely lowland and irrigated, were found at Tillabéry. The lowland agrosystem included floating rice in deep-water and lowland (paddy) rice production, with water levels below $0.5 \mathrm{~m}$. The irrigated agrosystem included large-scale irrigation schemes (86.3\%) under the control of local farmers' unions (assisted by ONAHA's agricultural extension officer), followed by floating rice (5.2\%), private irrigated rice (4.6\%), and lowland rice (3.9\%). The transplantation of 20 -day-old seedlings during the rainy season and 30- to 40-day-old young plants during the cool period was the main sowing method because of the predominance of irrigated agrosystems. In addition to this, a few farmers had started transplanting in the lowland fields because they found it easier for weeding and harvesting. Farmers in the deep-water agrosystem still practiced broadcast seeding. The size of the fields varied from 0.17 ha to more than 3 ha, with a variation across agrosystems. In irrigated rice, fields ranged between 0.17 and 1 ha. The majority of farmers on large-scale irrigated schemes had 0.25 ha, while private farmers had at least 0.5 ha. Lowland farmers possessed even bigger fields of 1 ha to more than 3 ha.

Prior to planting, all farmers used animal traction for field preparation. In irrigated agrosystems used for double cropping: the first season starts in June to July while the second season starts in December to January. A single cropping is practiced every year from June to July to November to December in the lowland agrosystem. Most farmers planted only rice $(90.2 \%)$, while a few farmers (9.8\%) combined rice with okra and rosella. Most farmers $(79.8 \%)$ practiced once or twice weeding during the cropping season, while $17.6 \%$ weeded three times and $2.6 \%$ four times. Only farmers in irrigated agrosystems used the herbicide Londax ${ }^{\mathrm{Tx}}$ for weed control, at rates ranging from 50 to $200 \mathrm{~g} \mathrm{ha}^{-1}$ (71.9\% used $100 \mathrm{~g} \mathrm{ha}^{-1}$ ). Fertilizer was applied as NPK and urea, mostly at 200 to $300 \mathrm{~kg} \mathrm{ha}^{-1}(66.5 \%)$. Some farmers (13.2\%) used less than $200 \mathrm{~kg} \mathrm{ha}^{-1}$, while $13.8 \%$ used more than $350 \mathrm{~kg} \mathrm{ha}^{-1}$ and $9 \%$ used 400 to $500 \mathrm{~kg} \mathrm{ha}^{-1}$.

Few farmers (15.7\%) use organic manure, and they did not apply fertilizer in lowland rice. Farmers used cultivars whose cycles ranged from 3 to 7 months and varying according to cultivar and agrosystem where they grow. Long cycle cultivars were grown in lowland deep-water agrosystems. Rice was harvested with traditional serrated knives by $79.7 \%$ of the farmers, whereas $20.3 \%$ used sickles. Traditional silages were still being used for storage by $31.4 \%$ of farmers, whereas $68.6 \%$ stored their harvest in rooms in their houses. The majority of farmers (52.2\%) noted postharvest losses due to rats (61\%), termites (13.4\%), mold (8.5\%), combinations of these factors (13.4\%), and thieves (3.7\%). Besides rice, the majority of farmers grew pearl millet (88.2\%), sorghum (44.4\%), cowpea (23.5\%), onion (10.5\%), sesame (9.8\%), maize (7.2\%), and tobacco (3.9\%). Onion, sesame, and tobacco were mainly 'cash crops.'

\section{Farmers' seed source and cultivar preferences}

Table 1 summarizes the main sources of seed supply. At the community level, the main seed source was the local farmers' union (78.6\%). The local farmers' union itself got certified seed from the Saguia farm (57.2\%) under the supervision of the ONAHA. Nearly all the farmers' unions that where visited however complained of the high level of contamination in seed bags from this source. The seed farm was supplied foundation seeds by the Institut National de la Recherche Agronomique du Niger (INRAN), which is also in charge of cultivar development, testing, and release. INRAN uses new breeding lines developed by the AfricaRice and partners and does the certifying of seed quality. A high percentage of farmers (64.2\%) used seeds from their previous harvest or borrowed seeds from fellow farmers in the same village. Hence, re-seeding (using their own seed) and seed exchange within villages constituted the predominant informal seed systems, followed by seed

Table 1 Main seed sources for $\mathbf{1 5 3}$ farmers in the region of Tillabéry

\begin{tabular}{lllll}
\hline & First seed source (\%) & Second seed source (\%) & Third seed source (\%) & Total (\%) \\
\hline Certified seed (Saguia farm-ONAHA) & 57.2 & - & - & 57.2 \\
Local farmers' union & 14.3 & 64.3 & 28.6 & 78.6 \\
Previous harvest & 21.4 & 14.3 & 35.7 & 64.3 \\
Other farmer (same village) & 7.1 & 21.4 & 28.6 & 64.2 \\
Other farmers (different village) & - & - & 7.1 & 28.6 \\
Institut National de la Recherche & - & - & & 7.1 \\
Agronomique du Niger (INRAN) & & & \\
\hline
\end{tabular}


exchange between villages (28.6\%). On rare occasions, some farmers received seed directly from INRAN (perhaps through participatory varietal selection), prior to varietal release. There was no evidence of any private seed company in the rice sub-sector in Niger.

Local farmers' unions rely mainly on selected farmers for seed multiplication. Thus, $81 \%$ of the farmers recognized the presence of seed producers in their community. The number of seed producers ranged from nil, in Gourey Bio and Sawani, to 49 in Saga, with an average of 12 producers per union. Nearly $17 \%$ farmers participated in seed production training. A $X^{2}$ test performed on the data revealed significant differences $(P=0.04)$ between the proportion of farmers that attended at least once seed production training and those without any formal seed production experience.

The majority of farmers (59.5\%) cultivated only one rice cultivar per season, while $31.4 \%$ of the farmers cultivated two, $8.5 \%$ three, and few farmers $(0.7 \%)$ up to four rice cultivars per season. Depending on the agrosystem, some rice cultivars were more frequently grown by farmers than others (Table 2). Most farmers in irrigated system preferred the IR1529 (30.7\%) and its farmer's bred-derivative cultivar 'Waihidjo' (35.3\%). Apparently, farmers adopted
'Waihidjo' readily because of its phenotypic similarity with IR1529 and only distinguishable by the presence of awns on the grains. These two cultivars were cropped on $15.8 \%$ and $17 \%$ of the surface of the interviewed farmers' fields, while $7.2 \%$ and $1.3 \%$ of the farmers grew 'Kardjikoyo' and 'Bassirou Mo' (also 'bred' by other farmers), respectively. Farmers also grew the newly released lowland New Rice for Africa (NERICA) cultivars NERICAL39 and NERICAL49 (13.7\% and $4.6 \%$ of the farmers on $7.5 \%$ and $2.1 \%$ of the surface, respectively). WITA8 and WITA9, which were released in 1997 because of their RYMV tolerance, were grown $6.5 \%$ and $1.3 \%$ of the farmers, respectively, on $3.7 \%$ and $1.1 \%$ of the surface. The lowland agrosystem was largely dominated by the cultivar 'Degaulle', with $17.6 \%$ of the farmers and $23.7 \%$ of the land cultivated. The African rice landraces 'Mala,' 'Barkanaye,' and 'Hara Massay' were also grown in the lowland agrosystem.

Grain yield was the main reason (33.5\%) for farmers to adopt a cultivar, followed by a combination of high yield and good taste $(10.2 \%)$, novelty $(9.2 \%)$, and good taste (8.7\%). High market value rice was also appreciated (5.4\%) along with good milling quality (4.9\%). Only $2.9 \%$ and $3.9 \%$ of the farmers accepted new rice cultivars due to resistance to pathogens and pests or survival under flood,

Table 2 Rice cultivars status, area planted, and type grown in the region of Tillabéry

\begin{tabular}{|c|c|c|c|c|c|}
\hline Rice cultivars & Status $^{a}$ & Frequency $(\%)^{\mathbf{b}}$ & Area planted (\%) & Type & Agrosystem \\
\hline Waihidjo (Kassimo) ${ }^{c}$ & NR & 35.3 & 17.0 & sativa & Irrigated \\
\hline IR1529 & $\mathrm{R}$ & 30.7 & 15.8 & sativa & Irrigated \\
\hline Degaulle/D52 & $L / R$ & 17.6 & 23.7 & sativa & Lowland \\
\hline NERICAL39 & $\mathrm{R}$ & 13.7 & 7.5 & sativa & Irrigated \\
\hline Gambiaka & $\mathrm{R}$ & 9.2 & 4.5 & sativa & Irrigated \\
\hline Kardjikoyo $^{c}$ & NR & 7.2 & 3.4 & sativa & Irrigated \\
\hline WITA8 & $\mathrm{R}$ & 6.5 & 3.7 & sativa & Irrigated \\
\hline Mala & L & 5.9 & 7.6 & glaberrima & Lowland \\
\hline Dogonbaraw & NR & 5.2 & 4.4 & sativa & Both \\
\hline NERICAL49 & $\mathrm{R}$ & 4.6 & 2.1 & sativa & Irrigated \\
\hline Barkanaye & L & 3.3 & 2.6 & glaberrima & Lowland \\
\hline Hara Massay & L & 2.6 & 2.6 & glaberrima & Lowland \\
\hline WITA9 & $\mathrm{R}$ & 1.3 & 1.1 & sativa & Irrigated \\
\hline Maï alewa & NR & 1.3 & 0.6 & sativa & Irrigated \\
\hline Pontompormi & $\mathrm{R}$ & 1.3 & 0.9 & sativa & Irrigated \\
\hline Bassirou $\mathrm{Mo}^{\mathrm{c}}$ & NR & 1.3 & 0.4 & sativa & Irrigated \\
\hline Motafiya & NR & 0.7 & 0.2 & sativa & Irrigated \\
\hline Soumana Gourara & $\mathrm{R}$ & 0.7 & 0.2 & sativa & Irrigated \\
\hline Mo Aro & NR & 0.7 & 0.2 & sativa & Irrigated \\
\hline Locki & NR & 0.7 & 1.0 & sativa & Irrigated \\
\hline TGR 48 & $\mathrm{R}$ & 0.7 & 0.5 & sativa & Irrigated \\
\hline
\end{tabular}

${ }^{a}$ Status: NR: not released, R: officially released, L: landrace.

${ }^{\mathrm{b}}$ Total more than 100 because of multiple responses.

'Cultivar 'bred' by a local farmer. 
respectively. Some lowland rice farmers (3.4\%) continued growing cultivars due to heritage (they inherited them from their parents) while few others (1.5\%) grew deepwater floating rice cultivars due of their adaptation to this agrosystem.

Farmers indicated that IR1529 was the most abandoned cultivar (34.6\%) followed by WITA8 (18.3\%) and 'Waihidjo' (17.6\%). Some farmers also abandoned newly released NERICAL39 (5.2\%) and NERICAL49 (2.3\%) whereas the old high yielding but RYMV-susceptible BG 90-2 was abandoned by $2.6 \%$ of the farmers. 'Gambiaka' had the smallest percentage $(0.7 \%)$ of abandonment among cultivars released in the last decade. Cultivar susceptibility to a pathogen or pest was cited by $27.6 \%$ as the first reason and by $22.1 \%$ as second reason for changing it. IR1529 and BG 902 were noted as high yielding but susceptible cultivars. Similarly, some farmers (mainly in Bonfeba, Namari Goungou, and Diambala) cited disease susceptibility as the main reason leading them to abandon of NERICAL39 and NERICAL49, after just one season of testing. The second reason for changing a rice cultivar was the availability of a new one with a higher grain yield (18.6\%). Some farmers (11.2\%) acknowledged however of being capable of abandoning their cultivars to test novelty. This finding confirms the influence of local farmers' unions in varietal testing and acceptance by farmers. Farmers abandoned some cultivars (IR1529 and 'Degaulle') because of seed degeneration and failure to renew the seed stock. Some farmers' unions rejected farmer-bred 'Waihidjo' and WITA8 because of its poor milling quality, which caused grain depreciation, thus resulting in a low market value. Other farmers abandoned WITA8 and WITA9 because of the relative importance of the straw, compared to the grain yield at harvest. Farmers in the irrigated agrosystem indicated that the pericarp color and the taste were also assessed to adopt new cultivars. Some farmers did not like red pericarp while aromatic and low to medium starch were desirable by them. Farmers do not appreciate long cycle cultivars and those requiring large quantity of fertilizer (for example, IR1529) in the irrigated rice agrosystem. Drought, particularly at an early vegetative stage before the raising of water levels, was the main reason for changing cultivars in the lowland agrosystem. Some farmers abandoned rice cultivars that could not grow fast enough to match the rapid increase of water levels during the rainy seasons. There was seed shortage because a few farmers consumed their seeds and thus be forced to 'abandon' a lowland rice cultivar that they still preferred.

The seed farm of Saguia, under the responsibility of the ONAHA, is the main and only source of certified rice seed for local farmers' unions, who united into a federation of rice farmers' unions of Niger (FUCOPRI). It is clear that the lack of other seed companies competing with the Saguia Farm has had a negative impact on the rice seed sub-sector of Niger. This monopoly cannot be however the sole explanation for the shortage of certified seeds to reach small-scale farmers in the country. The official rice seed supply in Niger has undergone changes during the last 20 years (from state-led intervention to farmers' association-led intervention) but with less impact than expected. In addition to the lack of competition, this situation is affected by the shortage of qualified seed inspectors and a clear and strict national seed policy to ensure access to quality seed by smallholders. The promotion and creation of small private seed enterprises could gradually enhance farmers' access to seed and may revitalize the rice seed system and complement the local informal seed supply.

Understanding farmers' perceptions of rice cultivars and varietal preferences are crucial in order for plant breeding to have the expected impact on rural community development. Farmers in the irrigated agrosystem of Tillabéry preferred IR1529 mainly because of its high yield and good grain quality (namely taste and milling ability), which makes it a cultivar with high market value. Such characteristics met the goals of both the producers (male farmers, who were willing to pay production charges and get benefits) and the post-harvest processors (female traders). In some regions, rice subsector actors did not find as many desired traits in one cultivar. IR1529 was however cited as the most abandoned recently, mainly because of its high susceptibility to RYMV and its high input requirements. AfricaRice [9] identified this cultivar as one of the main causes of RYMV epidemics in Niger.

Participatory varietal selection (PVS) is a powerful tool for rapid delivery of promising varieties to farmers [17]. This tool was used to deliver the RYMV-tolerant WITA8 as well as NERICAL39 and NERICAL49 to farmers. The expected impact of WITA8 was however affected by the high frequency of grain breakage during milling, while the interspecific lowland NERICAs showed susceptibility. The PVS process should be improved and if doubts persist, a pilot-scale distribution of the selected cultivar could be introduced in the system. The farmers' informal seed system will then disseminate or reject it, as was successfully used with upland rice in Ghana [22].

\section{Farmers' perception of major constraints on rice production}

The perception of constraints varied significantly $\left(\chi^{2}=\right.$ 30.12 , degrees of freedom $=18 ; P=0.03$ ) between agrosystems. RYMV was perceived by $31 \%$ of the farmers as the main pathogen in irrigated rice and also by $33.3 \%$ of the farmers across all agrosystems. Bacterial leaf blight (BLB) caused by Xanthomonas oryzae was cited as the second most important in irrigated ecosystems. Whitefly (Aleurocybotus indicus) and stem borers (Chilo zacconius) were perceived by farmers $(10.3 \%)$ to be equally serious problems in 
irrigated agrosystems. Birds, spiders, salinity, and other damage-inducing factors were cited as minor constraints. In the traditional lowland agrosystem, birds, hippopotamuses, and natural disaster (drought and flood) were perceived as contributing equally to reduce rice production. Across agrosystems, stem borer and RYMV are perceived to be more damaging in comparison to birds, BLB, and hippopotamuses.

Local names, main symptoms, period of infection or infestation, causes, and management strategies of biotic and abiotic stresses as cited by farmers are summarized in Table 3. Overall, farmers were aware of stresses affecting rice as well as the period of infection or infestation. The local naming for some pests refers usually to a visual description of the resulting disease symptoms. The causes of the disease were not accurate, and none of the farmers mentioned a description of bacteria or viruses during the PRA. More surprisingly, only 2 out of 11 ONAHA heads mentioned the word 'virus' and 'bacteria' when describing the causal agent of the two most important pathogens affecting rice in this region. Like the farmers, they cited 'worms', either in the soil or in the plant, to be the cause of RYMV and BLB. Consequently, when contacted by farmers about RYMV or BLB in their fields, they systematically recommended using pesticides (mainly Di-methoate and Furadan). The latter was banned from the European Union, partially in the United Sates and will be likely in Kenya due to potential health and environmental hazards. This inappropriate practice also increased production costs for farmers and thus reduced their incomes. Besides consulting local agricultural offices, farmers also used local knowledge such as applying ash, applying millet glumes and lemma, and organic manure for disease management. Individually, a large majority (90.2\%) of the interviewed farmers had experienced RYMV in their rice crops, thus a significant difference in farmers' experience of managing RYMV. RYMV was more important on the irrigated perimeter under the control of the ONAHA (96.2\%), followed by the lowland (83.3\%) and finally the private irrigation sector (71.4\%). Contrary to this, the incidence was lower in floating rice ecologies (12.5\%).

The majority of farmers (91.6\%) noted the disease symptoms just after the application of urea; that is, about 15 to 30 days after transplanting, which corresponds to the tillering stage. Most of the farmers (65.9\%) cited leaf yellow symptoms by using the words Larabo or Olalo, which mean 'the Arabic' or the 'yellow one.' The other 15\% of the farmers named RMYV as Tiguiro or Tchoukki (meaning 'the one that is static' or 'the dwarf') after the second more noticed symptoms; that is, stunting growth. Several farmers cited the aquatic grass Echinochloa pyramidalis (called 'Bourgou' in Sonrai language), the two wild rice species Oryza barthii ('Sombay') and Oryza longistaminata
('Baou'), and rice crop debris as RMYV hosts. For some, RYMV symptoms were caused by 'worms', humidity, the white fertilizer (urea), and for others, God. For $34.8 \%$ of the farmers, the disease symptoms are first noted on plants near the field's borders, while $26.8 \%$ did not recognize any pattern to the epidemic. For a few farmers (8\%), the disease started around the irrigation channels near the irrigation riser pipes, while $15.2 \%$ cited the middle of the field as the starting point. The same proportion found that the epidemic started at the place in the field where the previous harvest was threshed or the lowest point of the field where water usually stagnates.

Once RYMV symptoms were spotted in a field, $56.9 \%$ of the farmers took some action, including drying the field, then applying ash, destroying diseased plants, or simply notifying the ONAHA extension officer, who generally recommended applied Di-methoate or Furadan. The remaining farmers admitted to taking no action either because they deemed it unnecessary or hopeless. Indeed, yield losses due to RYMV were estimated to range from $50 \%$ to $60 \%$ by $55.1 \%$ of the farmers, while $13.2 \%$ estimated it to range between $70 \%$ and $80 \%$. Thus, contrary to curative action, nearly all farmers (97.8\%) agreed to prevent RYMV, after a season of attacks. Fields were cleaned, early plowed, and dried (57.8\%) to eliminate the disease. Stubble burning of previously infected sites as well as threshing sites were necessary for $20 \%$ of the farmers to prevent a new attack. A few farmers $(2.2 \%)$ did not know any prevention strategy. The failure to use varietal resistance as an RYMV prevention strategy was confirmed by the fact that only $2.8 \%$ of the farmers declared having tested a cultivar primarily because of its resistance to RYMV.

\section{Conclusions}

The main constraints on rice production as perceived by farmers were consistent with previous research $[9,10$, 23-25]. Although the cause of the RYMV remained a mystery to farmers, their naming of the disease was consistent with scientific naming despite several synonyms (all derived from the two main characteristics of the disease 'yellowing' and 'stunting'). The periods of appearance, as well as the symptoms, were consistent with the summary of RYMV's symptoms as compiled by several authors $[10,26,27]$. Farmers had yet to acknowledge the relationship between the pests and RYMV, though they recognized the role of weed and wild rice species in the disease cycle. In Tillabéry, some of the methods of transmission of RYMV were well understood and priority was given to prevention through stubble burning and cleaning. The role of rice seedbeds was however neglected, and the same plows were used in a given area. The farmers were not aware of the involvement of cows, donkeys, and rice seedbeds in the movement and persistence of RYMV, despite other sanitation practices $[13,28,29]$. 
Table 3 Summary of main biotic and abiotic constraints on rice production

\begin{tabular}{|c|c|c|c|c|c|c|}
\hline Constraint name & Effect on rice & Causes & $\begin{array}{l}\text { Time of } \\
\text { infection }\end{array}$ & Control measures & Local names (LN) & Translation of LN \\
\hline Birds & Suction of spikelets & Birds, drought & $\begin{array}{l}\text { Milk stage, } \\
\text { maturity }\end{array}$ & Guardians (two rice bags/guardian/season & Sassa, Tsounsayé & Birds \\
\hline $\begin{array}{l}\text { Bacterial leaf blight } \\
\text { (BLB) (Xanthomonas } \\
\text { oryzae spp.) }\end{array}$ & $\begin{array}{l}\text { Drying and rotting of } \\
\text { leaves, milky drops }\end{array}$ & Soil worms, unknown & $\begin{array}{l}\text { Tillering, } \\
\text { booting }\end{array}$ & $\begin{array}{l}\text { Apply ash, pesticides, elimination of diseased } \\
\text { plants }\end{array}$ & $\begin{array}{l}\text { Bouharora, Wiharora, } \\
\text { Goura }\end{array}$ & Kill in the water \\
\hline $\begin{array}{l}\text { Borers (Chilo } \\
\text { zacconius B.) }\end{array}$ & $\begin{array}{l}\text { Drying of panicles, rotting } \\
\text { of the 'heart' }\end{array}$ & $\begin{array}{l}\text { Plant worms, } \\
\text { butterflies }\end{array}$ & $\begin{array}{l}\text { Booting, } \\
\text { milk stage }\end{array}$ & Generally none, sometimes pesticides & $\begin{array}{l}\text { Djindegoro, Bon } \\
\text { kwaraye, kofo, Goro- } \\
\text { goro, Kolo-wiyo }\end{array}$ & Neck sting, white head, 'heart killer' \\
\hline Drought & $\begin{array}{l}\text { Drying and death of } \\
\text { seedling }\end{array}$ & God & $\begin{array}{l}\text { Seeding, } \\
\text { tillering }\end{array}$ & Late sowing & Kogay & Drought, lack of water \\
\hline Flood & $\begin{array}{l}\text { Rotting of plants and } \\
\text { death }\end{array}$ & God & $\begin{array}{l}\text { Seeding, } \\
\text { tillering }\end{array}$ & Early sowing & Hari ngayan & 'Eaten' by water \\
\hline $\begin{array}{l}\text { Hippopotamus } \\
\text { (Hippopotamus } \\
\text { amphibius L.) }\end{array}$ & $\begin{array}{l}\text { Destruction of fields, } \\
\text { feeding of plants }\end{array}$ & $\begin{array}{l}\text { Overprotected by } \\
\text { the government }\end{array}$ & $\begin{array}{l}\text { From } \\
\text { tillering to } \\
\text { harvest }\end{array}$ & Guardians (60 USD/guardian/sector & Ba nga & Hippopotamus \\
\hline Pests & $\begin{array}{l}\text { Injuries to leaves and } \\
\text { spikelets }\end{array}$ & $\begin{array}{l}\text { God, good rainy } \\
\text { season }\end{array}$ & $\begin{array}{l}\text { Booting, } \\
\text { milk stage }\end{array}$ & Generally none, sometimes pesticides & A nga riya, doyzo, fara & Insects, grasshopper \\
\hline $\begin{array}{l}\text { Rice yellow mottle } \\
\text { virus (RYMV) }\end{array}$ & $\begin{array}{l}\text { Yellowing of leaves, } \\
\text { height reduction, blackish } \\
\text { and empty panicles }\end{array}$ & $\begin{array}{l}\text { Worms, high } \\
\text { humidity, 'white } \\
\text { fertilizer' (urea), } \\
\text { unknown }\end{array}$ & $\begin{array}{l}\text { Tillering } \\
\text { after } \\
\text { application } \\
\text { of urea }\end{array}$ & $\begin{array}{l}\text { Apply ash from millet glume and glumelles, } \\
\text { drying fields, pesticides, elimination of diseased } \\
\text { plants, sometimes none, inefficient }\end{array}$ & $\begin{array}{l}\text { Ola, Olalo, Tiguiro, } \\
\text { Larabo, Dori Sayo, } \\
\text { Tchoukki, Bellayze } \\
\text { tchira }\end{array}$ & $\begin{array}{l}\text { The yellow one, the dwarf, the } \\
\text { Arabic man, the Touareg man, the } \\
\text { one with light complexion }\end{array}$ \\
\hline Salinity & $\begin{array}{l}\text { Discoloration and death } \\
\text { of leaves, yield reduction, } \\
\text { low tillering }\end{array}$ & Salt in the soil & Anytime & $\begin{array}{l}\text { Apply millet glume and glumelle, organic } \\
\text { manure }\end{array}$ & Sosso & Bicarbonate \\
\hline $\begin{array}{l}\text { Spiders (species } \\
\text { unknown) }\end{array}$ & $\begin{array}{l}\text { Trap seedling, reduce } \\
\text { vigor }\end{array}$ & God & Seedling & Destruction of cobwebs, none & Dadara & Spider \\
\hline Unknown & $\begin{array}{l}\text { Whitening of seedlings' } \\
\text { leaves }\end{array}$ & Unknown & Seedling & Apply ash, usually none & Kofa & Unknown \\
\hline $\begin{array}{l}\text { Weedy rice (species } \\
\text { unknown) }\end{array}$ & $\begin{array}{l}\text { Invades fields, seed } \\
\text { degeneration }\end{array}$ & $\begin{array}{l}\text { Transformation of } \\
\text { rice over time to wild } \\
\text { rice }\end{array}$ & $\begin{array}{l}\text { Anytime, } \\
\text { but visible } \\
\text { at heading }\end{array}$ & $\begin{array}{l}\text { Elimination of invasive plants (usually young } \\
\text { farmers could not differentiate from rice) }\end{array}$ & Sombay & Wild rice, O. barthii \\
\hline $\begin{array}{l}\text { Whitefly } \\
\text { (Aleurocybotus } \\
\text { indicus D. and S.) }\end{array}$ & $\begin{array}{l}\text { Honeydew on leaves and } \\
\text { sheath }\end{array}$ & $\begin{array}{l}\text { Flies, high density } \\
\text { transplanting }\end{array}$ & Booting & Apply ash, drying fields, sometimes none & Katou, You & Honey \\
\hline
\end{tabular}

As described by farmers in the region of Tillabéry. 
In summary, Niger must implement a national seed policy that restructures the formal seed sector and opens it to non-government organizations and small private enterprises. Additionally, staff of Saguia seed farm, seed producers of local farmers' association, as well as seed inspectors should be trained in appropriate seed production and policies. Prior to any PVS, rice researchers should screen promising breeding lines in controlled conditions against the RYMV and BLB, so that susceptible lines can be discarded. These lines as well as the popular IR1529/'Waihidjo' and 'Degaulle'/ D5237 need to be bred for resistance to RYMV and BLB. In addition, 'Degaulle'/D5237 could also be improved to withstand flood, by introgressing the gene SUB1. Widely adopted and popular farmer-bred cultivars also deserve the attention of genetic resources enhancement and plant health management research. Farmers in the region of Tillabéry are aware that RYMV is the main constraint that poses a threat to rice production. Moreover, they recognize the importance of good cropping practices and apply some prevention methods. More training on integrated pest management and awareness on environmental issues are needed for both farmers and ONAHA extension officers. If implemented, these recommendations may contribute toward increasing rice production in the region and improving farmers' livelihoods.

\section{Competing interests}

The authors declare that they have no competing interests.

\section{Authors' contributions}

MS, ML, and M-NN did the conception and design, data collection and analysis, manuscript writing, and final approval of the manuscript. IMM participated in the data collection, critical revision, and final approval of the manuscript. PAS and $\mathrm{RO}$ participated in the critical revision and final approval of the manuscript. All authors read and approved the final manuscript.

\section{Acknowledgements}

We thank the research funding from AfricaRice and USAID through a grant to the project 'Marker-assisted selection for the improvement of rice cultivars resistance to RYMV for West Africa.' The authors are also thankful to AfricaRice scientists involved in this study, mainly Dr. Aliou Diagne and his team for helping to develop the questionnaire, the database, and processing of the data. The authors are grateful to the ONAHA, INRAN, and the members of farmers' unions of all the localities visited for their administrative and logistic support.

\section{Author details}

'Africa Rice Center (AfricaRice), 01 BP 2031 Cotonou, Benin. ${ }^{2}$ Institut National de la Recherche Agronomique du Niger (INRAN), BP 429 Niamey, Niger.

${ }^{3}$ School of Agricultural, Earth and Environmental Science, College of Agriculture, Engineering and Science, University of KwaZulu-Natal (UKZN), 1 Carbis Road, Scottsville, Pietermaritzburg 3201, South Africa. ${ }^{4}$ Department of Plant Breeding, Swedish University of Agricultural Sciences, Box 101, Alnarp, SE 23053, Sweden.

Received: 22 October 2014 Accepted: 24 March 2015

Published online: 23 April 2015

\section{References}

1. Sido A. Etat des lieux de la riziculture: Cas du Niger. Projet Espagnol sur la riziculture en Afrique de l'Ouest. Niamey, Niger: Institut National de la
Recherche Agronomique du Niger - Food and Agriculture Organization of the United Nations; 2010

2. WFP: Niger. Italy, Rome: World Food Programme; 2010, http:/www.wfp.org/ countries/niger Accessed 10 November 2010.

3. Faivre-Dupaigre B, Allahoury A, Eychenne D, Gado B, Koure A, Moha A. Propositions pour une politique rizicole au Niger. Montpellier, France: Projet Pafriz, IRAM; 2006.

4. INS. Annuaire statistique des cinquante ans d'indépendance du Niger. Niamey, Niger: Institut National de la Statistique; 2010. http://www.stat-niger.org/ statistique/file/Annuaires_Statistiques/Annuaire_ins_2010/serie_longue.pdf Accessed 21 November 2012.

5. Seybou Y, Kodako Y. Etude sur l'Approfondissement du Diagnostic et l'Analyse des Systèmes de Production Agro-sylvo-pastoraux dans les Régions dans le Cadre de la Mise en Place de la Strategie de Developpement Rural: Région de Tillabéry. Niamey, Niger: Comite Interministeriel de Pilotage de la Strategie de Developpement Rural Secretariat Executif; 2004.

6. Alfari I, Garba I, Salifou I. Rapport d'étude: Détermination des surfaces et estimation de la production de Riz Hors Aménagement Hydro-Agricole (RHA). Niamey, Niger: Projet Pafriz, AGRHYMET; 2006.

7. Bonkoula A, Miezan K. Collecte des riz au Niger (Régions de Sinder et Kollo). Rapport de mission. Abidjan, Côte d'Ivoire: ORSTOM; 1982

8. Reckhaus PM, Adamou J. Field observations and field research on RYMV in the Republic of Niger. Paper presented at the IRTP-Africa Workshop at ICIPE Duduville, Kenya, 20-23 March 1989.

9. WARDA. Rice yellow mottle virus. In: Annual Report 2000. Bouaké, Côte d'Ivoire: West Africa Rice Development Association; 2001. p. 27-37.

10. Abo ME, Sy AA, Alegbejo MD. Rice yellow mottle virus (RYMV) in Africa: evolution, distribution, economic significance on sustainable rice production and management strategies. J Sustain Agric. 1998;11:85-111.

11. Issaka S, Basso A, Sorho F, Onasanya A, Haougui A, Sido AY, et al. Diagnosis and importance of rice yellow mottle disease epidemics in Niger Republic. J Appl Biosci. 2012;50:3501-11.

12. Konate G, Sarra S, Traore O. Rice yellow mottle virus is seed-borne but not seed transmitted in rice seeds. Eur J Plant Path. 2001;107:361-4. doi:10.1023/a:1011295709393.

13. Traoré $\mathrm{O}$, Traoré $\mathrm{M}$, Fargette $\mathrm{D}$, Konaté $\mathrm{G}$. Rice seedbeds as a source of primary infection by Rice yellow mottle virus. Eur J Plant Path. 2006;115:181-6.

14. Sow EM. Genetic diversity of Oryza species from Niger; screening and breeding for resistance to the Rice yellow mottle virus (RYMV), PhD thesis. Pietermaritzburg, South Africa: University of Kwazulu Natal; 2012. 2012.

15. Röling NG, Hounkonnou D, Offei SK, Tossou R, Van Huis A. Linking science and farmers' innovative capacity: diagnostic studies from Ghana and Benin NJAS Wageningen J Life Sci. 2004;52:211-23.

16. Efisue A, Tongoona P, Derera J, Langyintuo A, Laing M, Ubi B. Farmers' perceptions on rice varieties in Sikasso region of Mali and their implications for rice breeding. J Agron Crop Sci. 2008;194:393-400.

17. Joshi KD, Witcombe JR. Participatory varietal selection in rice in Nepal in favourable agricultural environments - a comparison of two methods assessed by varietal adoption. Euphytica. 2002;127:445-58.

18. Kiros-Meles A, Abang M. Farmers' knowledge of crop diseases and control strategies in the regional state of Tigrai, northern Ethiopia: implications for farmer-researcher collaboration in disease management. Agr Hum Val. 2008:25:433-52

19. Chambers R. Relaxed and participatory appraisal: notes on practical approaches and methods for participants in PRA/PLA related familiarisation workshops. Brighton, United Kingdom: IDS; 2002.

20. Lundy ME, Fischer AJ, Kessel CV, Hill JE, Ruark MD, Linquist BA. Surfaceapplied calcium phosphate stimulates weed emergence in flooded rice weed technology. 2010;24:295-302.

21. Zossou E, Van Mele P, Vodouhe SD, Wanvoeke J. Women groups formed in response to public video screenings on rice processing in Benin. Intl J Agric Sustain. 2010;8:270-7.

22. Dorward P, Craufurd P, Marfo K, Dogbe W, Bam R. Improving participatory varietal selection processes: participatory varietal selection and the role of informal seed diffusion mechanisms for upland rice in Ghana. Euphytica. 2007;155:315-27.

23. Balasubramanian V, Sie M, Hijmans RJ, Otsuka K. Increasing rice production in sub-Saharian Africa: challenges and opportunities. Adv Agron. 2007;94:55-133. 
24. Reckhaus PM. Occurrence of bacterial blight of rice in Niger, West Africa. Plant Dis. 1983;67:1039.

25. Traoré O, Pinel-Galzi A, Sorho F, Sarra S, Rakotomalala M, Sangu E, et al. A reassessment of the epidemiology of rice yellow mottle virus following recent advances in field and molecular studies. Virus Res. 2009;141:258-67.

26. Bakker W. Rice yellow mottle, a mechanically transmissible virus disease of rice in Kenya. Neth J Plant Path. 1970;76:53-63.

27. Banwo OO. Rice yellow mottle virus (RYMV) disease: a national problem in Tanzania. Acta Phytopathologica et Entomologica Hungarica. 2003;38:99-107.

28. Sarra S, Peters D. Rice yellow mottle virus is transmitted by cows, donkeys, and grass rats in irrigated rice crops. Plant Dis. 2003;87:804-8.

29. Sarra S, Oevering P, Guindo S, Peters D. Wind-mediated spread of Rice yellow mottle virus (RYMV) in irrigated rice crops. Plant Pathol. 2004;53:148-53.

\section{Submit your next manuscript to BioMed Central and take full advantage of:}

- Convenient online submission

- Thorough peer review

- No space constraints or color figure charges

- Immediate publication on acceptance

- Inclusion in PubMed, CAS, Scopus and Google Scholar

- Research which is freely available for redistribution 